\title{
Creating an academic literacy framework to enhance collaboration between learning developers and subject academics
}

\author{
Rosella D'Alesio \\ Swansea University
}

Ben Martin

Swansea University

\section{Abstract}

As learning developers, we are constantly engaging with subject lecturers to discuss the learning needs of our students. This case study describes the creation of an academic literacy framework designed to engage subject lecturers and improve collaboration between them and the learning development team in order to develop the academic skills of students. Our aim was to create a tool that would achieve three complementary goals:

- Help subject lecturers pinpoint where their students are placed along a spectrum of skills.

- Allow lecturers to request, and/or learning developers to recommend, skills sessions at the most appropriate time.

- Allow the learning development team to identify gaps in provision.

We used our experience as learning developers together with existing frameworks and schema to create a generic academic literacy framework for all disciplines. Because we perceived the HE level descriptors to be unsuitable for our needs, we aimed to create a framework that was not tied to specific levels. Once the framework was drafted, it was shared with other learning developers and subject academics to assess its suitability. This process provided results that confirmed we were moving towards an overall consensus and that the framework was fit for purpose.

Keywords: academic literacy framework; study skills; curriculum design; embedded skills; higher education; student experience. 


\section{Background}

As members of a team of learning developers, we deliver general academic skills courses that are open to the whole student body (level 3 foundation to level 7 master's and $\mathrm{PhD}$ students) as well as conducting one-to-one student consultations. We also work within colleges to provide embedded skills or bolt-on provision. We realised that there was a lack of understanding among subject lecturers of the potential benefits of collaborating with us. Therefore, we wanted a tool to help us in this endeavour and set ourselves the following goals for the framework. It had to be:

- Clear to understand.

- Easy to use.

- Of meaningful benefit to both students and staff.

In addition, we took the view that, for this framework, we had to work from an academic literacies approach in which academic socialisation and study skills are incorporated 'into a more encompassing understanding of the nature of student writing within institutional practices' (Lea and Street, 1998, p.158). For this reason, we decided not to base the framework on existing HE level descriptors, as our experience told us that these are not always representative of the true nature of a student's competence in academic skills. We wanted to provide academics with a tool that clearly allows them to see where their students are with regard to their academic skills on a particular learning journey, where they need to be, and how that gap can be bridged using our expertise. Furthermore, we wanted to ensure that students are able to master and communicate their knowledge in a meaningful way beyond the confines of their academic spaces. A final aim was that the framework would address alternative means of assessment, such as presentations, and how students could be prepared for them.

\section{Issues and Priorities}

Some of the issues we faced and priorities we decided on are outlined in this section. Our experience as learning developers within HE tells us that students are not always where we and subject lecturers think they should be on their learning and skills development 
pathway. Thus, there was a problem deciding how we would make distinct differences between HEFCE level descriptors. Skills acquisition is not necessarily linear, and it could be argued that acquiring skills and developing skills are quite distinct processes - the first is about gaining knowledge of the skill; the second is practising that skill. Students do not arrive at university equipped with the same skills, and this scenario is unlikely to change given the current tendency towards admitting students with lower entry tariffs as part of widening participation or for other reasons (Adams, 2019). Even in the rare case that students are homogenous and share the same starting point, their journey is often unpredictable, and individuals will travel at different speeds through the various stages.

Given this, we estimated that subject academics might not be able to easily identify where their students are on any given continuum of study skills acquisition. It was for this reason that an early discussion among the working group creating the framework was titled 'Where are your students?' (D'Alesio et al., 2018) and has driven much of what we have achieved. It was also for this reason that a cognitive approach based on a revised Bloom's taxonomy (Krathwohl, 2002) was our guide, as subject academics would be familiar with this approach.

One clear priority for us was that the framework should address the fact that students might, for example, have strong writing skills but not be able to recognise and create arguments, or have strong critical thinking skills but be lacking in knowledge of academic vocabulary. It was also a priority for us that academics understood that we had moved away from a deficit approach model that was outdated, not valuable and insensitive. Finally, we wanted to ensure that the document catered for students of all levels. Literacy development might be 'something that all students encounter as they shift from secondary school into postsecondary education' (Lea and Street, 2006, p.369), but skills development also continues throughout the academic journey. We aimed to cater for all students by including knowledge creation, peer review and contributing to knowledge dispersal, thus acknowledging the needs of students conducting research or development work. Another issue we faced was ensuring that we were clear in our intentions but without giving so much detail that stakeholders would be deterred from using the tool. We felt that many of the frameworks we looked at suffered from this problem. Therefore, we decided to group academic skills into three broad overarching dimensions that together covered all 
the areas necessary, namely: learning, communicating, and evaluating and conceptualising arguments. These skills encompassed both written and verbal communication. This seems to be a strength of the framework because, for learning developers, the framework is intuitive to use and it embodies what we teach in distinct, yet easy to understand spheres.

A major challenge we faced was not just what to include but what to exclude. We deliberately did not include any form of digital or information literacy as these are not within the remit of what we deliver and in our institute are delivered by other stakeholders. We also excluded mathematical and assessment literacies as we deemed them not to be within our sphere of expertise.

Finally, we hoped that the framework would act as a management tool, a check to help us identify gaps in our own provision. We envisaged that this could come about in two ways: firstly, subject academics requesting specific sessions we did not already provide, and secondly, from matching the courses and workshops we currently offer to each of the areas of the framework.

\section{Process}

Initially we assumed that an academic literacy framework already existed that would suit our needs or which could be modified if necessary. We looked at a number of existing academic skills and literacy frameworks to help us form an idea of what we wanted to achieve and more importantly to understand what we did not want. Through our experience of EAP, we were already familiar with BALEAP's 'Can-do' framework (BALEAP, 2013), an extremely useful and detailed breakdown of discrete academic skills required at master's level and, as demonstrated by Smith and Thondhlana (2015), just as useful at undergraduate level. However, we realised that even if we adapted such a document, our subject academics were unlikely to consult such a detailed text, no matter how useful. We also looked at the 'Academic Literacy Development Framework' (Harper, 2011), but we found it was not one that we could map easily against our provision; while we learning developers could appreciate the discrete skills detailed, we estimated that the subject academics with whom we worked would not be as concerned with the detail. The 
Academic Literacy Writing Framework spiral (Allen et al., 2011) posed two main challenges for us: firstly, it only considered academic writing skills, while we very much wanted to include verbal communication, and secondly, it prescribed what students needed at levels 4 through to 7. As already noted, we wanted to avoid prescriptive level descriptors, as we already know that many higher education students are not so easy to categorise.

Unable to find what we wanted, we set other models aside and decided to create our own. We were now clear that it needed to be a continuum of skills with clearly defined parameters, while also being a practical, usable document. We devised a matrix with an $\mathrm{x}$ axis labelling the learner stages, which we initially categorised as engaged learner, developing learner, autonomous learner and contributing learner, and a $Y$ axis labelling the academic skills group (learning, communicating, and evaluating and conceptualising arguments).

Figure 1. Extract from the Academic Literacy Framework: Learning and reflective practice from draft 2 [see Appendix 2 for complete version]

\begin{tabular}{|c|c|c|c|c|}
\hline $\begin{array}{l}\text { Learning and } \\
\text { reflective } \\
\text { practice }\end{array}$ & $\begin{array}{l}\text { Aware of a } \\
\text { range of } \\
\text { learning } \\
\text { techniques } \\
\text { such as } \\
\text { reflective } \\
\text { practice, time } \\
\text { management, } \\
\text { memory, } \\
\text { revision, } \\
\text { reading and } \\
\text { notetaking, } \\
\text { and can } \\
\text { respond to } \\
\text { feedback. }\end{array}$ & $\begin{array}{l}\text { Beginning to } \\
\text { understand } \\
\text { concepts } \\
\text { behind } \\
\text { learning } \\
\text { techniques. } \\
\text { Developing a } \\
\text { recognition of } \\
\text { personal } \\
\text { learning needs } \\
\text { through } \\
\text { incorporation } \\
\text { of feedback. }\end{array}$ & $\begin{array}{l}\text { Uses } \\
\text { concepts, } \\
\text { reflects and } \\
\text { actively seeks } \\
\text { feedback to } \\
\text { create own } \\
\text { learning } \\
\text { strategies to } \\
\text { meet personal } \\
\text { learning } \\
\text { needs. }\end{array}$ & $\begin{array}{l}\text { Refines } \\
\text { learning } \\
\text { strategies } \\
\text { through } \\
\text { reflection. } \\
\text { Helps others } \\
\text { develop their } \\
\text { own learning } \\
\text { strategies and } \\
\text { engage with } \\
\text { feedback } \\
\text { within their } \\
\text { community of } \\
\text { practice. }\end{array}$ \\
\hline
\end{tabular}


Once the skills for each section had been outlined, we conducted a mapping exercise to match our courses and workshops to the vectors we had created (see Figure 2 for a snapshot).

Figure 2. Example of provision mapped against Academic Literacy Framework.

\begin{tabular}{lll}
\hline Learning & Communicating & $\begin{array}{l}\text { Evaluating and } \\
\text { conceptualising arguments }\end{array}$ \\
\hline Quoting and Paraphrasing & Grammar Basics & Critical thinking \\
Academic Vocabulary & Presentation Skills & Literature review \\
Reading & Public Speaking & Advanced Academic Writing \\
Study Hacks & Post Graduate Research Writing & Doctoral Writing group
\end{tabular}

The next stage was to seek feedback from critical friends. We used the draft version in meetings with academics looking to embed our provision in their courses. The response was overwhelmingly positive; they fed back that seeing the skills laid out in this way allowed them to clearly pinpoint the needs of specific groups at specific moments. As we had anticipated, the needs of students at a particular level did not all fall in the same band, reinforcing our decision to move away from level descriptors.

We also obtained feedback from lecturers and asked them to critically comment on the document. We collated this feedback and took a revised version to conferences. We did this twice, first to the Swansea SALT Learning and Teaching Conference and then an amended version to the ALDinHE conference in Exeter (Appendix 1 and 2 respectively).

At both conferences, our objectives were twofold:

1. To explore whether our descriptions of the different stages of learning were clear and logical enough that it could be 'reverse engineered', i.e. could it be put back together if all levels and descriptors of levels were separated?

2. To discuss the following topics:

- What are the strengths of this framework?

- What are the weaknesses of this framework? 
- Is this framework helpful for you? If so, how? In what ways can you envisage using it?

- Would you use it when advising students and/or if a student came to you for help?

- Is this framework helpful for your students? If so, how?

- Are there any changes you would make? Please explain.

\section{Feedback}

Our first objective was almost universally met. The framework, which had been cut into pieces, was put back together like a jigsaw in the way we had designed it, showing that our description of the skills, and the progression of levels was logical. However, this did generate healthy discussion about how appropriate it might be for universal use. One of the outcomes of this discussion was to remove the $x$-axis labelling. We had deliberately stayed away from levels, stages or steps and instead tried to name the level of learner. However, it seems that these labels were distracting or inaccurate (for example, there was much discussion over whether a learner should be called engaged or novice), and on reflection we decided that they added no value to the framework, as they are merely labels. As it was correctly pointed out, are not all learners developing learners and are we not all developing in what we do?

Regarding our second objective, the following main points come from discussion with other learning developers and subject academics.

\section{Strengths}

- Great for students.

- Avoids deficit model of student help - good for stronger students too.

- Shows learning as it should be - continually evolving.

- Very useful as a formative learning framework that can be used to situate someone's learning and their progression in learning. 
- Provides programme directors with some useful benchmarks which might be mapped against the embedding of academic skills provision in programmes.

- Formalises the process that will keep teachers on track and provide the students with a better understanding of their learning process and what to expect.

\section{Gaps/Weaknesses}

- Disengaged/novice/uninformed learners are not considered but are perhaps the students who need the most help.

- Too much jargon, e.g. 'academic register'. Students will find the jargon difficult to understand. especially those students for whom English is not their first language.

\section{Discussion and Next Steps}

The discussions we have had about the framework have been positive overall. There were many comments - both positive and negative - about its suitability for students. Heartening though it was to hear that this would be useful for students, at this stage we were designing it for academics; designing for students will be a separate task at a future date. Regarding the main weaknesses, we felt that the weakest students are provided for but that the student must be 'engaged' to progress. Perhaps doing away with those labels, as described above, will solve that issue.

With regard to the technical terms, we feel that subject academics would understand the concepts. It is our intention to create a student version of the framework, and this must be achieved with input from students to make it suitable for students to use.

Currently, the framework is one-dimensional. We feel there is scope to develop it into an online artefact where clicking on certain vectors would lead to another layer of information. Moving into the new academic year, we intend to use the tool with academic staff who engage with us regarding new skills provision. To date, there has been interest from other institutes, and it would be interesting to explore how they have adapted the framework. We would also be interested in working with colleagues to develop the project further by 
sharing the framework with other learning development teams and receiving feedback on the implementation of the framework within their institutes.

\section{References}

Adams, R. (2019) 'Universities told to be more flexible about pupils' A-level results', The Guardian, 1 May. Available at:

https://www.theguardian.com/education/2019/may/01/universities-told-to-be-moreflexible-about-pupils-a-level-results (Accessed 18 November 2019).

Allen, R., Lundie Hill, K., Jarvis, J., Lawrence, E., Roberts, A., Solly, D. and Woodward, J. (2011) The academic writing/feedback cycle: an exploration through collaborative staff/student research. Available at:

http://www.studynet1.herts.ac.uk/tic.nsf/Teaching+Documents/C50F4C9FF3478C0 F80257E96004CF993/\$FILE/The\%20academic\%20writingfeedback $\% 20$ cycle $\% 20$ and $\% 20$ exploration $\% 20$ through $\% 20$ collaborative $\% 20$ staffstudent\%20research\%20(ARoberts).pptx (Accessed 18 November 2019).

BALEAP (2013) BALEAP Can Do Framework: Competency statements for international students (Master's level). Available at: https://www.baleap.org/wpcontent/uploads/2016/04/Can Do Framework with sample activities April 2013. pdf (Accessed 18 November 2019).

D'Alesio, R., Tanguay, E., Chartier, N. and Yeandle, H. (2018) 'Where are your students?', SALT Conference. Swansea University, Swansea 18 July.

Harper, R. (2011) Academic Literacy Development Framework. University of Canberra; Academic Skills Centre. Available at: http://www.aall.org.au/clpd/aall2011/Downloads/ppts/Harper ALDF.pdf (Accessed 18 November 2019). 
Krathwohl, D.R. (2002) 'A revision of Bloom's taxonomy: An overview', Theory into Practice, 41(4), pp.212-218.

Lea, M.R. and Street, B.V. (1998) 'Student writing in higher education: An academic literacies approach', Studies in Higher Education, 23(2), pp.157-172.

Lea, M.R. and Street, B.V. (2006) 'The" academic literacies" model: theory and applications', Theory into Practice, 45(4), pp.368-377.

SCONUL Working Group on Information Literacy (2011). The SCONUL seven pillars of information literacy: core model for higher education. Available at: https://www.sconul.ac.uk/sites/default/files/documents/coremodel.pdf (Accessed 18 November 2019).

Smith, A. F. and Thondhlana, J. (2015) 'The EAP competencies in a group case study project as revealed by a task analysis', Journal of English for Academic Purposes, 20, 14-27.

\section{Author details}

Rosella D'Alesio is the Academic Success Programme Director for The Centre of Academic Success at Swansea University.

Ben Martin is a Study Skills Lecturer in Swansea University's Centre for Academic Success. 


\section{Appendix 1}

The Academic Literacy Framework First Draft

\begin{tabular}{|c|c|c|c|c|}
\hline & $\begin{array}{l}\text { Engaged } \\
\text { Learner }\end{array}$ & $\begin{array}{l}\text { Developing } \\
\text { Learner }\end{array}$ & $\begin{array}{l}\text { Autonomous } \\
\text { Learner }\end{array}$ & $\begin{array}{l}\text { Contributing } \\
\text { Learner }\end{array}$ \\
\hline Learning & $\begin{array}{l}\text { Aware of } \\
\text { techniques }\end{array}$ & $\begin{array}{l}\text { Begin to } \\
\text { understand } \\
\text { concepts and } \\
\text { why assessment } \\
\text { methods are } \\
\text { used; } \\
\text { developing } \\
\text { recognition of } \\
\text { personal } \\
\text { learning needs }\end{array}$ & $\begin{array}{l}\text { Motivated } \\
\text { students } \\
\text { who use } \\
\text { concepts to } \\
\text { create own } \\
\text { learning } \\
\text { strategies; } \\
\text { meet } \\
\text { personal } \\
\text { learning } \\
\text { needs }\end{array}$ & $\begin{array}{l}\text { Honing } \\
\text { learning } \\
\text { strategies }\end{array}$ \\
\hline Communicating & $\begin{array}{l}\text { Structure - } \\
\text { ideas clearly } \\
\text { separated; } \\
\text { relevance; } \\
\text { logical } \\
\text { progression } \\
\text { Voice - } \\
\text { accurate use } \\
\text { of language } \\
\text { and use of } \\
\text { appropriate } \\
\text { academic } \\
\text { register }\end{array}$ & $\begin{array}{l}\text { Structure - } \\
\text { Developing a } \\
\text { range of } \\
\text { structural } \\
\text { devices and } \\
\text { methods of } \\
\text { presenting ideas } \\
\text { while } \\
\text { maintaining flow } \\
\text { Voice - develop } \\
\text { rhythm and use } \\
\text { of conventions } \\
\text { to enhance } \\
\text { communication; } \\
\text { voice becoming } \\
\text { appropriate for } \\
\text { audience }\end{array}$ & $\begin{array}{l}\text { Voice - } \\
\text { moves } \\
\text { beyond } \\
\text { accuracy to } \\
\text { skilled } \\
\text { selection of } \\
\text { language; } \\
\text { command of }\end{array}$ & $\begin{array}{l}\text { Disseminating } \\
\text { research to a } \\
\text { range of } \\
\text { audiences; } \\
\text { being an active } \\
\text { member of the } \\
\text { academic } \\
\text { community }\end{array}$ \\
\hline
\end{tabular}




\begin{tabular}{|l|l|l|l|l|}
\hline & & & $\begin{array}{l}\text { language } \\
\text { and rhythm; } \\
\text { range of } \\
\text { rhetorical } \\
\text { devices. } \\
\text { Voice } \\
\text { suitable for } \\
\text { audience }\end{array}$ & \\
\hline Evaluating & $\begin{array}{l}\text { Identify an } \\
\text { argument } \\
\text { and } \\
\text { appropriate } \\
\text { sources }\end{array}$ & $\begin{array}{l}\text { Analyse and } \\
\text { evaluate } \\
\text { arguments; use } \\
\text { a range of } \\
\text { sources to } \\
\text { support the } \\
\text { sound and } \\
\text { cogent } \\
\text { argument }\end{array}$ & $\begin{array}{l}\text { Contribute new } \\
\text { identify gaps } \\
\text { in research }\end{array}$ & the field \\
& & & \\
\hline
\end{tabular}




\section{Appendix 2}

\section{The Academic Literacy Framework Second Draft}

\begin{tabular}{|c|c|c|c|c|}
\hline & $\begin{array}{l}\text { Engaged Novice } \\
\text { Learner }\end{array}$ & $\begin{array}{l}\text { Developing } \\
\text { Learner }\end{array}$ & $\begin{array}{l}\text { Autonomous } \\
\text { Learner }\end{array}$ & $\begin{array}{l}\text { Contributing } \\
\text { Learner }\end{array}$ \\
\hline $\begin{array}{l}\text { Learning and } \\
\text { reflective practice }\end{array}$ & $\begin{array}{l}\text { Aware of a range } \\
\text { of learning } \\
\text { techniques such } \\
\text { as reflective } \\
\text { practice, time } \\
\text { management, } \\
\text { memory, revision, } \\
\text { reading and } \\
\text { notetaking, and } \\
\text { can respond to } \\
\text { feedback. }\end{array}$ & $\begin{array}{l}\text { Beginning to } \\
\text { understand } \\
\text { concepts behind } \\
\text { learning } \\
\text { techniques. } \\
\text { Developing a } \\
\text { recognition of } \\
\text { personal learning } \\
\text { needs through } \\
\text { incorporation of } \\
\text { feedback. }\end{array}$ & $\begin{array}{l}\text { Uses concepts, } \\
\text { reflects and } \\
\text { actively seeks } \\
\text { feedback to } \\
\text { create own } \\
\text { learning } \\
\text { strategies to } \\
\text { meet personal } \\
\text { learning needs. }\end{array}$ & $\begin{array}{l}\text { Refines learning } \\
\text { strategies } \\
\text { through } \\
\text { reflection. } \\
\text { Helps others } \\
\text { develop their own } \\
\text { learning } \\
\text { strategies and } \\
\text { engage with } \\
\text { feedback within } \\
\text { their community } \\
\text { of practice. }\end{array}$ \\
\hline Communicating & $\begin{array}{l}\text { Structure - ideas } \\
\text { clearly separated; } \\
\text { relevant, with } \\
\text { logical } \\
\text { progression } \\
\text { appropriate to } \\
\text { task. } \\
\text { Voice - accurate } \\
\text { use of language } \\
\text { and appropriate } \\
\text { academic } \\
\text { register. }\end{array}$ & $\begin{array}{l}\text { Structure - } \\
\text { developing a } \\
\text { range of } \\
\text { structural devices } \\
\text { and approaches } \\
\text { to presenting } \\
\text { ideas while } \\
\text { maintaining flow. } \\
\text { Voice - } \\
\text { developing } \\
\text { rhythm and use } \\
\text { of conventions to } \\
\text { enhance } \\
\text { communication. } \\
\text { Voice becoming } \\
\text { appropriate for } \\
\text { specific } \\
\text { audiences. }\end{array}$ & $\begin{array}{l}\text { Structure - clear } \\
\text { and logical } \\
\text { intention behind } \\
\text { structural } \\
\text { decisions. } \\
\text { Voice - moves } \\
\text { beyond accuracy } \\
\text { to skilled } \\
\text { command of } \\
\text { language and } \\
\text { rhythm; uses a } \\
\text { range of } \\
\text { rhetorical } \\
\text { devices. } \\
\text { Adapts voice } \\
\text { according to } \\
\text { specific } \\
\text { audiences. }\end{array}$ & $\begin{array}{l}\text { Disseminates } \\
\text { original and } \\
\text { genre- } \\
\text { appropriate } \\
\text { research to a } \\
\text { range of } \\
\text { audiences; is an } \\
\text { active member of } \\
\text { the academic } \\
\text { community. }\end{array}$ \\
\hline $\begin{array}{l}\text { Evaluating and } \\
\text { conceptualising } \\
\text { arguments }\end{array}$ & $\begin{array}{l}\text { Recognises } \\
\text { appropriate } \\
\text { sources. } \\
\text { Identifies } \\
\text { arguments within } \\
\text { these sources. } \\
\text { Summarises to } \\
\text { draw own } \\
\text { conclusion. }\end{array}$ & $\begin{array}{l}\text { Locates and uses } \\
\text { a range of } \\
\text { sources. } \\
\text { Analyses and } \\
\text { evaluates } \\
\text { arguments within } \\
\text { these sources. } \\
\text { Uses sources to } \\
\text { make and } \\
\text { support } \\
\text { arguments. }\end{array}$ & $\begin{array}{l}\text { Identifies gaps in } \\
\text { research. } \\
\text { Creates sound } \\
\text { and cogent } \\
\text { arguments. }\end{array}$ & $\begin{array}{l}\text { Provides } \\
\text { informed } \\
\text { feedback on } \\
\text { arguments to } \\
\text { students and/or } \\
\text { peers. Produces } \\
\text { materials that } \\
\text { contribute to the } \\
\text { academic debate } \\
\text { in the field. }\end{array}$ \\
\hline
\end{tabular}

